\title{
Jazyky a literatura Židů z interdisciplinární perspektivy
}

\author{
Petr Kučera (Plzeň)
}

Ve dnech 24.-26. 9. 2019 se na univerzitě v Augsburgu konala mezinárodní konference $\mathrm{s}$ názvem Zukunft der Sprache, Zukunft der Nation?, která reflektovala zejména debaty o židovském jazyce a židovské literatuře v kontextech vícejazyčnosti a utváření národa. Akce byla vyústěním projektu spolupráce univerzit v Augsburgu, Plzni a Černovicích. Bavorsko-česko-ukrajinská kooperace se opírá o tradice, které tyto středoevropské křižovatky spojují. Připomeňme, že kulturní centrum Švábska Augsburg má jednu z nejkrásnějších (secesních) synagog v Evropě, významné židovské muzeum, tradici hebrejského knihtisku, ale též univerzitu pěstující intenzivně judaistiku (zejména jidišistiku); bukovinské Černovice patřily k nejvýznamnějším centrům židovské kultury ve střední Evropě - židovské tradice se zde prolínaly s vlivy slovanskými, starorakouskými, rumunskými a mad’arskými; Plzeň, křižovatka hedvábné a zlaté stezky, měla po Praze druhou největší židovskou obec v Čechách, plzeňská Velká synagoga je třetí největší na světě (po jeruzalémské a budapeštské).

Interdisciplinární zaměření projektu a s ním spojené konference propojilo dílčí výzkumné projekty jidišistů, germanistů a slavistů v oborech lingvistiky, literární a kulturní historie. Evropští badatelé z Německa, Česka, Ukrajiny, Rakouska, Mad’arska, Rumunska, Francie, Švýcarska i mimoevropští z Izraele a USA se poctivě snažili vykročit z úzkých koridorů specializovaných vědních disciplín a vést nesnadný mezioborový dialog.

Výchozím tématem byla reflexe impulzů, které vnesla do života židovských obcí debata o možnostech jazykového utváření židovského národa a jeho literární kultury. Významnou roli v emancipačním hnutí sehrála konference v Černovicích v roce 1908 - význam konference zhodnotila ve svém referátu Evita Wiecki (Mnichov). Výhodou i nevýhodou jazyka jidiš je jeho výrazná heterogenita - morfosyntaktickou a lexikální bázi tvoří dialekty střední horní němčiny, nemalý byl vliv dialektů italštiny a francouzštiny, jakož i slovanských (zejména východoslovanských) jazyků. Země Koruny české byly křižovatkou jak z hlediska lingvistického (západní a východní varianta jidiš), ale i z pohledu kulturně historického (př́klon k habsburské monarchii a Vídni jako centru hospodářského i kulturního života či naopak směřování $\mathrm{k}$ Berlínu a centrům západní Evropy).

Díky silnému zastoupení ukrajinských badatelů (nejen z univerzity v Černovicích, ale i z německých a dalších univerzit) se zasloužené pozornosti dostalo sociolingvistické, literární a kulturní situaci Židů v Bukovině. Bukovinští vzdělanci usilovali po návratu z rakouských, německých a švýcarských univerzit o zřízení vlastní univerzity v Černovicích. Tato pozoruhodná enkláva, která je pojmem nejen několika národních, ale i evropských literárních a kulturních dějin, však nemohla odolat extrémně ničivé síle německého nacismu, rumunského fašismu a sovětského stalinismu. Dnešní univerzita v Černovicích usiluje v nelehkých podmínkách ukrajinské periférie o uchování paměti regionu, který je opomíjenou součástí stř̌edoevropského kulturního areálu.

Samostatný panel byl věnován problematice standardizace a kanonizace. Ze slavistického hlediska jsou zajímavé paralely, které nalézá Martina Niedhammer (Mnichov) srovnávací analýzou lexikografického úsilí o standardizaci jidiš a běloruštiny ve dvacátých a třicátých letech 20 . století. Anruo Bao (New York) spatřuje - na základě analýzy myšlenek Isaaca Leiba Peretze o možnostech kanonizace tradiční podoby jidiš - těžiště problému v pohledu na složitý a stereotypy zatížený vztah mezi jazykem a národem.

Účastníci z České republiky se v panelu zaměřeném na jazykové kontakty a volbu jazyka 
v židovských obcích Rakouska-Uherska soustředili na problémy polylingvismu a preference jazyka - Andrea Königsmarková (Plzeň) v případové studii o Spáleném Pořričí, na kulturní orientaci vícejazyčných židovských spisovatelů v některých západočeských a středočeských obcích - Petr Kučera (Plzeň), na prvky židovských etnolektů v české literatuře 20. a počátku 21. století - Štěpán Balík (České Budějovice); Boris Blahak (Plzeň) podnikl lingvoliterární exkurs do didakticky zaměřených próz Maxe Broda, ve kterých pražský spisovatel a představitel sionismu vytváří koncept jidiš jako jazyka moderního židovství; Ingeborg Fialová (Olomouc) představila poněkud opomíjenou německy psanou tvorbu židovských spisovatelek z Čech a Moravy.

Rostoucímu zájmu se těší problematika masmediálních diskurzů: Francisca Salomon (Iaşi) zkoumala obraz černovické konference a s ní spojeného úsilí o hledání židovské identity v dobovém tisku, Stefaniya Ptashnyk (Heidelberg) přiblížila reflexe jazykové a identitární krize v mediálních diskurzech v Haliči na přelomu 19. a 20. století, otázkám jazyka a židovské identity v meziválečné Haliči se věnovala také Vladyslava Moskalets (Lvov).

Na primárně lingvisticky orientovaných příspěvcích byl cenný zájem o kulturně historické a společensko-politické souvislosti. Joachim Hahn (Cáchy) reflektoval němčinu jako jazyk sionismu. Liliana Feierstein (Berlín) charakterizovala utopické naděje vkládané do esperanta jako jednoho z možných židovských jazyků. Sebastian Schirrmeister (Hamburg) zkoumal etnolingvistickou problematiku používání tzv. lámané hebrejštiny. Ágota Nagy (Oradea) uvažovala o „černovičtině“ třicátých let 20. století jako o specifické kontaktové varietě středovýchodoevropského urbanolektu na bázi německých dialektů a východní jidiš.

Konkrétní analýzy a interpretace, ale i metodologické podněty přinesly příspěvky literární jidišistiky a translatologie. Natalia Blum-Barth (Mohuč) nabídla pohled na literaturu počátku 20. století psanou v jidiš jako na cestu od experimentů k estetickému projektu. Carmen Reichert
(Augsburg) představila debaty o jazyce a jazyk autobiografií autorek píšících v jidiš. Katharina Baur (Augsburg) se pokusila vřadit do více kontextů Chasidská vyprávěni Pauly a Martina Buberových. Olha Flachs (Heidelberg) přiblížila prostřednictvím posledního románu Emila Franzose Der Pojaz okolnosti zákazu četby německých knih a používání němčiny ve východožidovském chasidismu jako vnitřní židovský identifikační konflikt. Sarah Stoll (Mnichov) interpretovala román Avedot Leaha Goldberga jako meta-literární román. Jan Kühne (Jeruzalém) předestřel problém bilingvní homonymie v německy psané židovské literatuře. Malena Chinski (Paříž) nastínila přístupy a možnosti francouzských překladatelů literatury jidiš. Na svědectví Wolfganga Hildesheimera v otázkách vícejazyčnosti, jakož i sionistické skepse k budování židovského státu (ve smyslu „ano vlasti národa, ale ne židovskému státu“) se zaměřil Stephan Braese (Cáchy). Armin Eidherr (Salcburk) prozkoumal diskurs o otázkách národa a jazyka ve sdruženích jidiš básníků po roce 1908.

Černovickému židovskému básníkovi evropského významu - Paulu Celanovi - se ve svém referátu věnoval Petro Rychlo (Černovice). Celan navazuje ve své německy psané hermetické poezii na metafyzické básníky první poloviny 20. století, zejména na pražského rodáka R. M. Rilka. Svůj vnitřní jazykový, umělecký a lidský konflikt (rodiče mu zavraždili nacisté $\mathrm{v}$ koncentračním táboře, a tak se tázal, zda je vůbec možné psát mateřským jazykem, je-li to zároveň jazyk matčiných vrahů) řešil vytvářením nového básnického jazyka plného zámlk, ticha, symbolů a aluzí, ale i prvků jazyka jidiš v neurastenických místech textů. I zde se ukázalo, že černovický pohled může mezinárodní debatu obohatit.

Snad nejcennější na konferenci v Augsburgu byla velice živá diskusní atmosféra, která umožňovala otevřený dialog i o problémech, které jsou v národních filologiích či literárně a kulturně historických syntézách zatíženy xenofobními či hegemonistickými stereotypy. Lze jen litovat, že tyto debaty probíhaly bez přítomnosti badatelů z Polska, Běloruska a Ruska. 
doc. Dr. Petr Kučera, Ph.D.

Katedra germanistiky a slavistiky

Filozofická fakulta, Západočeská univerzita v PIzni

Riegrova 11, 30614 Plzeň, CZ

pekucera@kgs.zcu.cz

Toto dílo Ize uží v souladu s licenčními podmínkami Creative Commons BY-SA 4.0 International (https://creativecommons.org/licenses/by-sa/4.0/legalcode). Uvedené se nevztahuje na díla či prvky (např. obrazovou či fotografickou dokumentaci), které jsou v díle užity na základě smluvní licence nebo výjimky či omezení príslušných práv. 